\title{
LEAN, AUTOMATION AND MODULARIZATION IN CONSTRUCTION
}

\author{
Sara Gusmão Brissi ${ }^{1}$ and Luciana Debs ${ }^{2}$
}

\begin{abstract}
The architecture, engineering and construction (AEC) industry lags behind the manufacturing industry, both in terms of innovation and productivity, mainly due to its heterogeneous, fragmented nature and the uniqueness of its projects. This paper analyzes three effective processes and technologies which are carrying out great benefits to the construction industry: lean construction, automation, and modularization (LAM). The research consists of a systematic literature review and assesses previously published work related to the three combined topics LAM in construction with two main goals: (1) identify the relevance of the three topics combined for both the AEC industry and the academy, and (2) identify in the papers investigated the main themes related to the combination of LAM in construction. Findings reveal only 31 publications meeting the criteria within the two sources investigated. The most frequent areas of LAM identified in the papers were lean production management, optimization algorithm and prefabrication, respectively related to lean construction, automation in construction and modular construction. The results reveal a need to better investigate the interactions of LAM in construction as a way to promote the continuous improvement of the AEC industry.
\end{abstract}

\section{KEYWORDS}

Lean construction, automation, modularization, off-site construction, continuous improvement.

\section{INTRODUCTION}

Over the last decades the productivity of the architecture, engineering and construction (AEC) industry has stagnated at low levels, with no sign of improvement, as opposed to several other industry sectors, such as manufacturing or the automotive industry (McKinsey Global Institute 2017). During the same time, many concepts, technologies, systems and materials have been introduced to the industry, but performance has not increased at the expected level (World Economic Forum 2016). Research suggest that this fact is due to two main reasons: the historical resistance of the AEC industry to embrace innovation into its traditional processes, and the lack of a holistic view to address the

1 PhD Student, School of Construction Management Technology - Purdue University, West Lafayette, Indiana, USA, sgusmaob@purdue.edu

2 Assistant Professor, School of Construction Management Technology - Purdue University, West Lafayette, Indiana, USA, Idecresc@purdue.edu 
problems identified in this fragmented sector (McKinsey Global Institute 2017; World Economic Forum 2016).

When applied to the AEC industry as a holistic system, the effectiveness of strategies involving lean construction, automated technologies and modular building systems has been confirmed by research (Altaf et al. 2018; Tillmann et al. 2015). Individually, each of these strategies aims to increase the productivity and quality of the construction industry. However, to this date, there is a lack of research to evaluate how those three strategies combined can boost the overall performance of the AEC industry.

\section{INTERACTIONS BETWEEN LEAN CONCEPTS, AUTOMATION, AND MODULARIZATION IN THE AEC INDUSTRY}

The industrialization of the AEC industry, involving modular construction strategies and automated process have the potential to dramatically increase productivity in the construction industry (Jensen et al. 2012). As in other industrial sectors, industrialized construction processes build on some important concepts: (1) production planning and control; (2) mechanization and automation of production processes, and (3) standardization or products and processes. These three concepts are closely related to lean construction, automation in construction, and modular construction, respectively.

Thinking of a construction project as a temporary production system, the goal of lean construction (LC) is to deliver a quality product built on value maximization and waste minimization, which means quality and productivity improvement (McGraw Hill Construction 2013). In fact, three key concepts are important to better understand lean constructions: value, flow and pull (Ballard and Howell 2003). In LC the meaning of "value" is not only cost, but mainly the customers' satisfaction. Flow refers to the movement of information and materials through all professionals involved with the project, including the production crews as well. Pull is related to planning techniques that control the flow of information and materials in a collaborative way, constantly monitoring the project schedule (Ballard and Howell 2003; Koskela et al. 2002). It is important to emphasize that construction in lean construction refers to the entire design and construction process and not only to the construction phase, as defined in the transformation-flow-value (TFV) theory (Koskela 2000).

The goal of automation is to reduce time, cost and human induced error in production processes, therefore, similarly to the lean concepts, automation should result in enhanced quality and productivity. Considering the AEC industry, automation can greatly enhance the design, construction, operation and maintenance processes of buildings. However, the construction industry is still reluctant to adopt new automation technologies capable of boosting its productivity, enhancing quality of its products and streamlining its project management procedures (McKinsey Global Institute 2017). Robotics applications, BIM tools, automated assembly lines of prefabricated modules, 4D simulations for planning and scheduling and laser scanning are some examples of important technologies whose use in AEC industry could be much more significant.

Modularization in construction is closely related to prefabrication because the modules are prefabricated, i.e. manufactured under controlled factory conditions, which assures better quality products, and more efficiency in processes and resources use. (McGraw-Hill 
Construction, 2011; McKinsey Global Institute, 2017). Modular buildings can bring together the advantages of both standardization and customization, as a result of the flexible use of standardized modules combined in various ways. Research suggests that breaking down complex systems into smaller components is a good problem-solving strategy in many domains, including the AEC industry, where modules designed independently must be integrated to work together in a complex structure such as a building, considering factors such as off-site manufacturing processes, transportation and on-site assembly (Jensen et al. 2012; Sharafi et al. 2017). Thus, modularization must also be closely linked to standardization, involving a holistic standardized production process to reduce not only the variability of each module, but also the complexity of the control processes.

Individually, the areas related to LAM in the AEC industry have been extensively researched in recent years. However, to date, there is little research dedicated to analyzing the relationships between these three areas at the same time. This study will provide an overview of the main topics related to the combination of lean, automation and modular construction that have been published in the last years and which topics are the most relevant ones.

\section{METHODOLOGY}

Our purpose is to explore, through a systematic literature review, the interactions between three effective processes and technologies applied to the construction industry which are carrying out great benefits to the sector: lean construction, automation in construction, and modular construction. That said, we address the following research questions:

- How much attention has the academy and the AEC industry devoted to the study of the combined topics lean construction, automation in construction and modular construction?

- What are the most relevant issues presented on publications that simultaneously investigate the topics related to lean, automation and modularization in construction?

\section{Data Collection and Data Analysis}

This study examines relevant papers which simultaneously analyze the topics related to LAM in the AEC industry between the years 2000 and 2018.

First, the researchers defined the terms associated to lean, automation and modularization in construction which should be used as keywords in the data selection and data analysis. The lean construction terms were defined according to Koskela's (2000) concepts of transformation, flow and value. The terms associated to automation and modularization in construction were also identified based on the literature. The main keywords identified are: (1) lean - continuous improvement, elimination waste, generation of value, optimization of process, last planner system, flow, lead time, just in time, JIT, six sigma, etc.; (2) automation: RFID (and related terms), BIM (and related terms), robotics (and related terms), sensing, algorithm, simulation, parameterization, etc.; (3) modular construction - modular, module, prefabrication, precast, parametric design, etc. 
The two sources selected to collect papers were the Automation in Construction (AIC) international research journal and the International Group for Lean Construction (IGLC) website. By considering these two contrasting sources of data, the study allows for a good overview of the current scenario of published papers that simultaneously cover the topics LAM in construction.

A total of 326 papers were retrieved from the AIC and IGLC websites using the following search criteria:

Automation in Construction - returned a total of 240 papers.

- Years: 2000-2018 (from January to December, including papers available online before published).

- Article type: review articles and research articles.

- Keywords: lean, modular building, modular construction, prefabrication, prefabrication AND lean, prefabrication AND modular.

International Group for Lean Construction - returned a total of 86 conference papers.

- Years: 2000-2018 (from January to December)

- Keywords: automated, automation, BIM, modular, prefab.

The selected papers were imported into NVivo and text mining queries were performed as follows (parameters - no spread and grouping with stemmed words):

- Considering that all the 86 papers from the IGLC are related to lean in construction, the researchers ran multiple text search queries using the keywords related to automation and modularization. After eliminating the duplicated papers, the content of each paper was manually assessed by the first author, who first looked for the defined keywords in the Title, Abstract and Keywords of each paper and then, if the related terms were not identified, the researcher assessed the full content of the paper. As a result of this process, a total of 12 papers with the joint content on LAM in construction were selected.

- Considering that all the 240 papers from the AIC are related to automation in construction, the researchers ran text search queries using the keywords related to lean construction and modularization. Here again the content of each paper was manually assessed, resulting in 19 papers with the joint content on lean, automation and modularization in construction.

A total of 31 papers addressing lean, automation and modularization in construction resulted from this selection.

Following, aided by NVivo and based on the defined keywords, the first author manually identified the topics of each paper related to LAM in construction. Based on the thematic analysis method (Braun and Clarke 2009), the researcher identified the themes emerging from the papers. The papers were then clustered by lean construction themes, based on the transformation-flow-value theory (Koskela 2000) and in the value, flow and pull concepts defined by Ballard and Howell (2003). 


\section{RESULTS AND DISCUSSION}

Results from our research indicate that in recent years, especially in 2018, AIC has published a growing number of papers that cover all three LAM topics - lean, automation and modular construction (Figure 1). However, for the IGLC the number of papers published that satisfy this criterion was more expressive in 2015 and have stabilized since 2017 with a couple per year (Figure 2).

The relation between the total number of papers published and the number of papers addressing the combined topic LAM in construction suggests a low degree of interest from both research and practice in exploring the interactions of LAM in construction. For example, the following numbers present the proportion of LAM papers that were published by AIC and IGLC in 2018:

- AIC magazine: in 2018 (Jan-Dec), 6 out of 313 (1.92\%) published papers addressed the combined topic LAM in construction.

- IGLC website: in 2018 (Conference IGLC 26 - Chennai, India), 2 out of 134 (1.49\%) published papers addressed the combined topic LAM in construction.

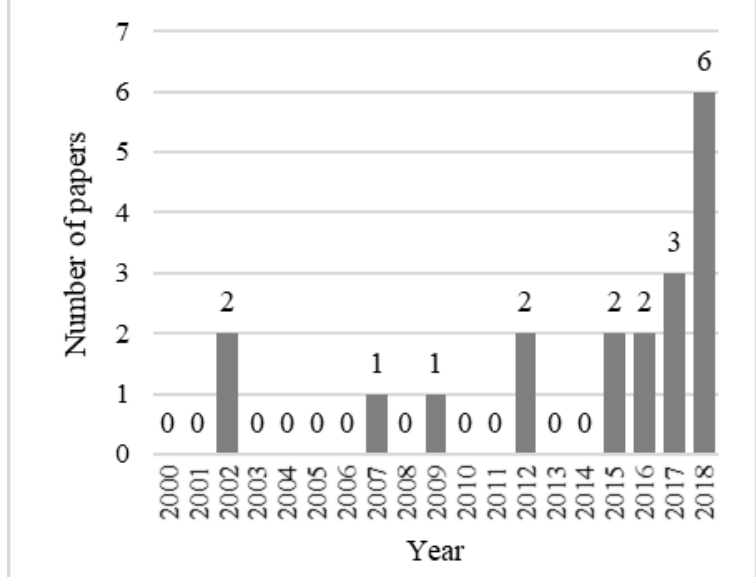

Figure 1: AIC LAM papers $(\mathrm{n}=19)$

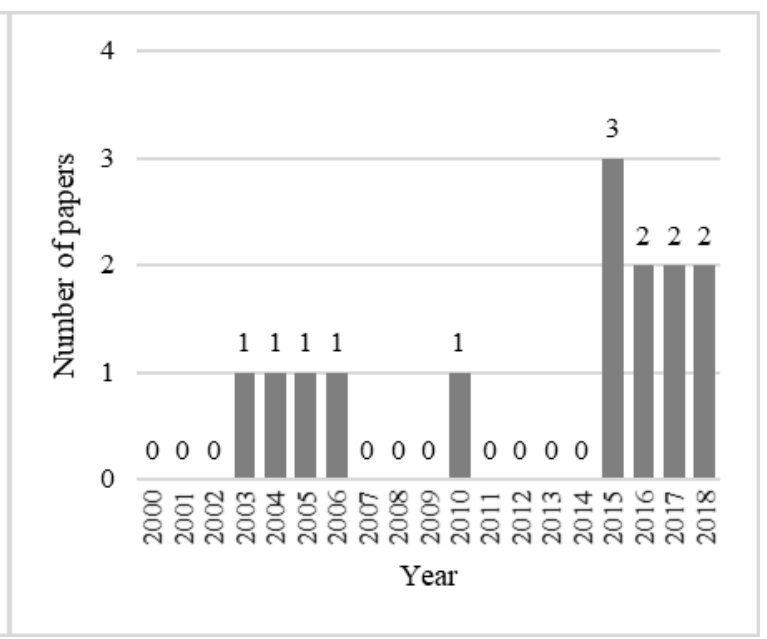

Figure 2: IGLC LAM papers $(\mathrm{n}=12)$

The topics related to LAM in construction, grouped by lean construction themes are presented in Table 1, with the most frequent topics related to lean construction, automation and modularization in construction shaded in grey.

Table 1: Main topics related to lean, automation and modularization in construction

\begin{tabular}{cccc}
\hline Author & $\begin{array}{c}\text { Lean Construction } \\
\text { Topics }\end{array}$ & $\begin{array}{c}\text { Automation in } \\
\text { Construction Topics }\end{array}$ & $\begin{array}{c}\text { Modular Construction } \\
\text { Topics }\end{array}$ \\
\hline Altaf et al. 2018 & Production planning and \\
control & $\begin{array}{c}\text { RFID, RANSAC model } \\
\text { optimization algorithm }\end{array}$ & $\begin{array}{c}\text { Panelized wall production } \\
\text { facility for prefabricated } \\
\text { homes }\end{array}$ \\
\hline Arashpour et al. 2015a & $\begin{array}{c}\text { Production planning and } \\
\text { control }\end{array}$ & $\begin{array}{c}\text { Autonomous production } \\
\text { tracking }\end{array}$ & $\begin{array}{c}\text { Off-site construction plant: } \\
\text { precast concrete tanks }\end{array}$ \\
\hline
\end{tabular}




\begin{tabular}{|c|c|c|c|}
\hline Author & $\begin{array}{c}\text { Lean Construction } \\
\text { Topics } \\
\end{array}$ & $\begin{array}{c}\text { Automation in } \\
\text { Construction Topics }\end{array}$ & $\begin{array}{c}\text { Modular Construction } \\
\text { Topics } \\
\end{array}$ \\
\hline Bataglin et al. 2017 & Logistics planning and control & 4D BIM modelling & $\begin{array}{c}\text { Logistics: Engineer-to-order } \\
\text { (ETO) concrete prefabricated } \\
\text { structures }\end{array}$ \\
\hline Bortolini et al. 2015 & $\begin{array}{l}\text { Logistics planning and control: } \\
\text { in construction sites }\end{array}$ & 4D BIM modelling & $\begin{array}{l}\text { Logistics: ETO prefabricated } \\
\text { building systems }\end{array}$ \\
\hline Gerber et al. 2010 & $\begin{array}{l}\text { Lean construction principles: } \\
\text { look ahead planning, design } \\
\text { and construction integration }\end{array}$ & $\begin{array}{l}\text { BIM: fabrication processes, } \\
\text { design and construction } \\
\text { integration }\end{array}$ & $\begin{array}{l}\text { Prefabricated components: } \\
\text { various }\end{array}$ \\
\hline Murphy et al. 2018 & $\begin{array}{l}\text { Lean construction principles: } \\
\text { predictability }\end{array}$ & $\begin{array}{l}\text { VDC methods and Reality } \\
\text { Capture }\end{array}$ & $\begin{array}{l}\text { Prefabrication: interior wall } \\
\text { panels }\end{array}$ \\
\hline Peñaloza et al. 2016 & Integrated production control & $\begin{array}{l}\text { 4D BIM: physical flows, } \\
\text { control of assembly process }\end{array}$ & $\begin{array}{l}\text { ETO prefabricated concrete } \\
\text { systems }\end{array}$ \\
\hline Cheng and Chen 2002 & $\begin{array}{l}\text { Controlling and monitoring } \\
\text { construction progress }\end{array}$ & $\begin{array}{l}\text { Automated schedule } \\
\text { monitoring system }\end{array}$ & Precast building construction \\
\hline Sacks et al 2003 & $\begin{array}{l}\text { Lean production and delivery: } \\
\text { monitoring }\end{array}$ & $\begin{array}{l}\text { Real-time automatically } \\
\text { monitoring \& 3D modelling }\end{array}$ & ETO: precast concrete pieces \\
\hline Tillmann & $\begin{array}{l}\text { Lean principles: lead time, } \\
\text { production planning and } \\
\text { control }\end{array}$ & BIM: integrated management & ETO components \\
\hline Zhong et al., 2017 & $\begin{array}{l}\text { Monitoring: visibility and } \\
\text { traceability in manufacturing, } \\
\text { logistics and on-site assembly }\end{array}$ & $\begin{array}{l}\text { Internet-of-Things \& BIM } \\
\text { real-time automated } \\
\text { monitoring }\end{array}$ & $\begin{array}{l}\text { Prefabricated construction: } \\
\text { manufacturing, logistics and } \\
\text { on-site assembly }\end{array}$ \\
\hline Arashpour et al. 2016 & $\begin{array}{l}\text { Scheduling: resource sharing } \\
\text { and job sequencing }\end{array}$ & $\begin{array}{l}\text { Optimization modeling } \\
\text { algorithm }\end{array}$ & $\begin{array}{l}\text { Off-site construction plant of } \\
\text { concrete panels }\end{array}$ \\
\hline Kong et & $\begin{array}{l}\text { Scheduling: cost and time } \\
\text { constraints integrating } \\
\text { manufacture, transportation } \\
\text { and on-site assembly (JIT) }\end{array}$ & $\begin{array}{l}\text { Dynamic programming } \\
\text { algorithm: maximum } \\
\text { production efficiency }\end{array}$ & $\begin{array}{l}\text { Precast construction: } \\
\text { manufacturing, transport, } \\
\text { delivery, on-site assembly }\end{array}$ \\
\hline \multicolumn{4}{|c|}{ LC Theme: Flow - Increase Flexibility } \\
\hline Arashpour et al. 2015 & $\begin{array}{c}\text { Multi-skilled resources: } \\
\text { flexibility, process integration }\end{array}$ & $\begin{array}{l}\text { Optimization modeling } \\
\text { algorithm - SIMAN code }\end{array}$ & Off-site construction plant \\
\hline Arashpour et al. 2018 & $\begin{array}{l}\text { Process integrations and multi- } \\
\text { skilled resources }\end{array}$ & $\begin{array}{l}\text { Optimization modeling } \\
\text { algorithm }\end{array}$ & Off-site construction plant \\
\hline Isaac et al. 2016 & $\begin{array}{l}\text { Flexibility: product } \\
\text { adaptability }\end{array}$ & $\begin{array}{l}\text { Clustering algorithm: design } \\
\text { graph-based analysis }\end{array}$ & $\begin{array}{c}\text { Modularization of building } \\
\text { design }\end{array}$ \\
\hline \multicolumn{4}{|c|}{ LC Theme: Waste Elimination (non-value-adding activities) } \\
\hline Banihashemi et al. 2018 & Waste reduction workflow & $\begin{array}{l}\text { Generative algorithm and } \\
\text { Modular coordination }\end{array}$ & $\begin{array}{l}\text { Parametric design and } \\
\text { modular coordination } \\
\text { integration }\end{array}$ \\
\hline Cheng et al. 2015 & $\begin{array}{l}\text { Waste reduction: construction } \\
\text { and demolition }\end{array}$ & $\begin{array}{l}\text { BIM: automated quantity } \\
\text { take-off, planning, design } \\
\text { reviews, clash detection and } \\
\text { digital fabrication }\end{array}$ & Digital prefabrication \\
\hline Yuan et al. 2018 & $\begin{array}{l}\text { Lean construction: simplify } \\
\text { design, manufacture and } \\
\text { assembly to reduce time and } \\
\text { costs }\end{array}$ & $\begin{array}{c}\text { Design for Manufacture and } \\
\text { Assembly-oriented parametric } \\
\text { design with BIM }\end{array}$ & $\begin{array}{l}\text { Prefabricated building design, } \\
\text { parametric components, } \\
\text { precast components }\end{array}$ \\
\hline
\end{tabular}




\begin{tabular}{|c|c|c|c|}
\hline Author & $\begin{array}{c}\text { Lean Construction } \\
\text { Topics } \\
\end{array}$ & $\begin{array}{c}\text { Automation in } \\
\text { Construction Topics }\end{array}$ & $\begin{array}{c}\text { Modular Construction } \\
\text { Topics }\end{array}$ \\
\hline \multicolumn{4}{|c|}{ LC Theme: Lean layout } \\
\hline Chen et al. 2018 & $\begin{array}{l}\text { Facility layout planning: } \\
\text { minimize production time and } \\
\text { maximize workstation use }\end{array}$ & $\begin{array}{l}\text { Automated guided vehicle- } \\
\text { based flow production system } \\
\text { and genetic algorithm }\end{array}$ & $\begin{array}{l}\text { Precast factory layout: } \\
\text { modular prefabricated } \\
\text { manufacturing system }\end{array}$ \\
\hline Cheung et & $\begin{array}{l}\text { Site precast yard layout to } \\
\text { minimize transport cost }\end{array}$ & Genetic algorithm model & $\begin{array}{l}\text { Precast: on site layout } \\
\text { arrangement }\end{array}$ \\
\hline Nasereddin et al. 2007 & $\begin{array}{l}\text { Lean construction: factory } \\
\text { more flexible, responsive, and } \\
\text { efficient }\end{array}$ & Automated modeling & $\begin{array}{l}\text { Modular home manufacturing } \\
\text { industry }\end{array}$ \\
\hline \multicolumn{4}{|c|}{ LC Theme: Pull System - Controlling Resources Flow } \\
\hline Liu and Lu 2017 & Supply chain management & $\begin{array}{l}\text { Constraint programming- } \\
\text { based optimization algorithm }\end{array}$ & $\begin{array}{l}\text { Supply chain and } \\
\text { module assembly plan }\end{array}$ \\
\hline Chin et al. 2004 & Supply chain management & $\begin{array}{l}\text { RFID: product and } \\
\text { information flow management }\end{array}$ & Supply chain: curtain walls \\
\hline Tiwari et al. 2018 & $\begin{array}{l}\text { Supply chain management and } \\
\text { job sequencing }\end{array}$ & $\begin{array}{l}\text { BIM: real-time sequencing } \\
\text { and digital fabrication }\end{array}$ & $\begin{array}{l}\text { Supply chain: light gauge } \\
\text { metal stud panels }\end{array}$ \\
\hline \multicolumn{4}{|c|}{ LC Theme: Visual Management - Transparency } \\
\hline Han et al. 2012 & $\begin{array}{c}\text { Lean production: Value Stream } \\
\text { Mapping (VSM) }\end{array}$ & $\begin{array}{c}\text { Automated post-simulation } \\
\text { visualization }\end{array}$ & $\begin{array}{l}\text { Modular building production } \\
\text { line }\end{array}$ \\
\hline \multicolumn{4}{|c|}{ LC Theme: Value - Customer Satisfaction (Quality, Cost and Time) } \\
\hline Benros and Duarte 2009 & $\begin{array}{l}\text { Customer satisfaction and mass } \\
\text { customization }\end{array}$ & Automated production & $\begin{array}{l}\text { Mass customized housing, } \\
\text { prefab building system }\end{array}$ \\
\hline Said et al. 2017 & $\begin{array}{l}\text { Flexibility and customer value: } \\
\text { mass customization and } \\
\text { platform design }\end{array}$ & $\begin{array}{c}\text { Algorithm: platform design } \\
\text { optimization }\end{array}$ & $\begin{array}{l}\text { Mass customization: exterior } \\
\text { panelized walls, module } \\
\text { design for prefabrication, }\end{array}$ \\
\hline Jensen et al. 2012 & $\begin{array}{l}\text { Customization: flow of } \\
\text { information - } \\
\text { customer/engineer/ production }\end{array}$ & $\begin{array}{l}\text { Design automation: } \mathrm{CAD} \text { and } \\
\text { manufacturing CAD tools }\end{array}$ & $\begin{array}{c}\text { Parameterization of building } \\
\text { components and } \\
\text { customization }\end{array}$ \\
\hline \multicolumn{4}{|c|}{ LC Theme: Miscellaneous } \\
\hline Pasquire et al. 2006 & Lean construction principles & Digital construction & Digital Prefabrication \\
\hline Xu et al. 2018 & $\begin{array}{l}\text { Lean construction: service- } \\
\text { sharing platform }\end{array}$ & $\begin{array}{l}\text { Integrated cloud-based IoT } \\
\text { platform }\end{array}$ & $\begin{array}{l}\text { Prefabricated construction: } \\
\text { production, logistics and on- } \\
\text { site assembly }\end{array}$ \\
\hline
\end{tabular}

A summary of the most frequent themes related to lean construction, automation and modularization in construction found by the thematic analysis is presented as follows:

Lean Construction:

- Lean Management - 11 papers. Related topics: planning, control, scheduling, monitoring, predictability, etc. Related terms: production, supply chain, logistics, multi-skilled resources, time, cost, process integration, resources, etc.)

Automation in Construction:

- Optimization Algorithm - 11 papers. Related topics: programming algorithm, genetic algorithm, generative algorithm, clustering algorithm, etc. Related terms: programming, modelling, constraint programming, etc. 
Modularization in Construction:

- Prefabrication -9 papers. Related topics: prefabricated construction, prefabricated building design, digital prefabrication, precast components, etc. Related terms: manufacturing, logistics, assembly, parametric design, etc.

Following, we discuss how the lean construction theme - Lean Management - connects to automation and modularization themes in the AEC industry domain.

\section{INTERACTIONS OF LEAN MANAGEMENT WITH AUTOMATION AND MODUlarization IN CONSTRUCTION THEMES}

\section{Lean Construction Theme: Lean Management}

Lean Management encompasses planning (Lean Work Structuring - LWS) and control (Last Planner System - LPS). Considering the papers analysed and the lean construction concepts (Koskela 2000; Koskela et al. 2002), LWS and LPS purposes are: (1) design and plan the whole construction process - manufacturing, transport and assembly; (2) identify repetitive processes; (3) implement standard process; (3) stablish collaborative schedules (pull scheduling); (4) define work plans; (5) eliminate workflow variability; (6) monitor productivity evolution; (7) actively control the workflow; (8) improve performance increase value.

According to previous research these goals are built on solid collaboration among the project stakeholders and constant monitoring and control, which fosters a sense of teamwork and transparency (Koskela 2000; Koskela et al. 2002).

\section{Automation and Modularization in Construction Themes}

The papers grouped under the lean management theme were clustered in four themes related to automation in construction: (1) algorithm; (2) BIM; (3) automated monitoring and tracking systems; and (4) virtual design and construction (VDC).

As for the modularization in construction themes, we have: (1) off-site construction facilities; (2) prefabrication; and (3) engineered-to-order (ETO) components.

Two papers discussed how algorithms can automate production processes, optimizing planning, control and scheduling in off-site construction facilities. The solution implemented in a prefabricated homes factory is based on an optimization algorithm which enables real-time scheduling and performance monitoring using the production data collected by radio frequency identification (RFID), whose noisy is automatically removed by a RANSAC model before being used in a simulation model and then, integrated with the optimization algorithm (Altaf et al. 2018). The other paper uses an optimization modelling algorithm to define the optimal product sequencing considering resource sharing and job sequencing for a concrete panels factory (Arashpour et al. 2016). Algorithm enhancing lean construction was also explored by Kong et al. (2017), who presents a dynamic algorithm that optimize scheduling for manufacturing, transportation and assembly of precast construction.

Prefabrication theme has many synergies with lean construction and BIM. BIM allows for automating many processes in the AEC industry, such as: drawing review, design 
coordination, scheduling, cost control, work monitoring, etc. In addition, BIM is paramount for automating construction processes by using robots and CNC process. The two papers addressing prefabrication and lean management interactions use BIM strategies to implement lean principles in the construction processes. BIM is used to automate fabrication processes, enhance design and construction integration and enable look ahead planning in projects using precast components for façades (Gerber et al. 2010). The internet of things (IoT) and BIM are presented as enablers of prefabrication process and lean management by automatically monitoring the manufacturing, logistics and on-site assembly processes (Zhong et al. 2017).

BIM and engineered-to-order (ETO) components interactions are discussed in five papers. 4D BIM modelling is used for planning and control logistics operations in ETO prefabricated building components (Bataglin et al. 2017; Bortolini et al. 2015). Integrated production control (design, manufacturing and assembly) in ETO prefabricated concrete building systems is automatically enabled by 4D BIM simulations (Peñaloza et al. 2016). The use of lean principles in the design-production interface of ETO components is presented as a means of leveraging BIM, which is used as support to management practices (Tillmann et al. 2015). Engineered-to-order (ETO) components synergies with lean management are enhanced by using 3D modelling and real-time monitoring (Sacks et al. 2003).

An automated schedule monitoring system enhances control and monitoring of precast building construction progress by integrating Geographic Information System (GIS) with a database management system (Cheng and Chen 2002). An autonomous production tracking mechanism for production management enables real-time scheduling updates (Arashpour et al. 2015a).

Finally, virtual design and construction (VDC) methods and reality capture technology are presented as a means to enhance design coordination, increase the predictability and provide feedback for site conditions in prefabricated wall panel design process (Murphy et al. 2018).

\section{CONCLUSIONS}

This study investigated the relevance of the combined topics lean, automation and modularization (LAM) in construction for research and practice. The authors performed a systematic literature review on papers from two sources, AIC journal and IGLC website, between 2000 and 2018. Results revealed a low number of papers $(n=31)$ approaching all LAM topics combined. In addition, published work connecting the three topics under analysis were found to be mainly focused on the following themes: (1) Lean construction - lean production management; (2) Automation in construction - optimization Algorithm; (3) Modularization in construction - prefabrication. The results reveal the existence of great research potential exploring the interactions of the set lean practices, automation and modularization in the AEC industry, as a way to enhance the industry performance and engage it in a process of continuous improvement.

The limitations of this study are related to the exploratory nature of this research and related to: (1) only using published papers from two sources; (2) findings were limited to the keywords used in the process of paper selection; and (3) the thematic analysis was 
carried out by only one researcher. An expanded research, considering published work from a larger number of academic sources, different keywords used to select the papers and two researchers working the thematic analysis is under way and may reveal a slightly different picture or confirm what was found in this study.

Recommendations for future research on the interactions of lean, automation and modularization in the AEC industry would include assess topics that are gaining more relevance in today's construction scenario - such as robotics (automation), integrated project delivery (lean), and parameterization of modules (modularization) - and the results of possible combinations of these topics for the AEC industry improvement.

\section{REFERENCES}

Altaf, M. S., Bouferguene, A., Liu, H., Al-Hussein, M., and Yu, H. (2018). “Integrated production planning and control system for a panelized home prefabrication facility using simulation and RFID." Automation in Construction, Civil and Environmental Engineering, University of Alberta, Edmonton, Canada, 85, 369-383.

Arashpour, M., Kamat, V., Bai, Y., Wakefield, R., and Abbasi, B. (2018). "Optimization modeling of multi-skilled resources in prefabrication: Theorizing cost analysis of process integration in off-site construction." Automation in Construction, Elsevier B.V., 95, 1-9.

Arashpour, M., Wakefield, R., Abbasi, B., Lee, E. W. M., and Minas, J. (2016). “Off-site construction optimization: Sequencing multiple job classes with time constraints." Automation in Construction, Elsevier B.V., 71, 262-270.

Arashpour, M., Wakefield, R., Blismas, N., and Maqsood, T. (2015a). "Autonomous production tracking for augmenting output in off-site construction." Automation in Construction, 53, 13-21.

Arashpour, M., Wakefield, R., Blismas, N., and Minas, J. (2015b). "Optimization of process integration and multi-skilled resource utilization in off-site construction." Automation in Construction, Elsevier B.V., 50, 72-80.

Ballard, G., and Howell, G. A. (2003). "Competing Construction Management Paradigms." Contruction Research Congress, Winds of Change: Integration and Innovation in Construction, Proceedings of the Congress, 1(October), 321-328.

Banihashemi, S., Tabadkani, A., and Hosseini, M. R. (2018). "Integration of parametric design into modular coordination: A construction waste reduction workflow." Automation in Construction, 88, 1-12.

Bataglin, F. S., Viana, D. D., Formoso, C. T., and Bulhões, I. R. (2017). “Application of Bim for Supporting Decisionmaking Related to Logistics in Prefabricated Building Systems." 25th Annual Conference of the International Group for Lean Construction, Heraklion, Greece, 71-78.

Benros, D., and Duarte, J. P. (2009). "An integrated system for providing mass customized housing." Automation in Construction, Elsevier B.V., 18, 310-320.

Bortolini, R., Shigaki, J. S.-I., and Formoso, C. T. (2015). "Site Logistics Planning and Control Using 4D Modeling: A Study in a Lean Car Factory Building Site." 23rd 
Annual Conference of the International Group for Lean Construction, O. Seppänen, V. A. González, and P. Arroyo, eds., Perth, Australia, 361-370.

Braun, V., and Clarke, V. (2009). "Thematic analysis." APA handbook of research methods in psychology, Vol 2: Research designs: Quantitative, qualitative, neuropsychological, and biological., 2(August), 57-71.

Chen, C., Tran Huy, D., Tiong, L. K., Chen, I. M., and Cai, Y. (2018). "Optimal facility layout planning for AGV-based modular prefabricated manufacturing system." Automation in Construction, Elsevier B.V., 1-12.

Cheng, M., and Chen, J. (2002). "Integrating barcode and GIS for monitoring construction progress." Automation in Construction, Elsevier B.V., 11, 23-33.

Cheung, S. O., Tong, T. K. L., and Tam, C. M. (2002). "Site pre-cast yard layout arrangement through genetic algorithms." Automation in Construction, Elsevier B.V., 11, 35-46.

Chin, S., Yoon, S. W., Jung, S. 0., Kim, Y. S., Kim, C. D., Choi, Y. K., Chun, J. Y., and Lim, H. C. (2004). "An Analysis of the Life-Cycle Curtain Wall Process Through Supply Chain Management." 12th Annual Conference of the International Group for Lean Construction, S. Bertelsen and C. T. Formoso, eds., Helsingør, Denmark.

Gerber, D. J., Becerik-Gerber, B., and Kunz, A. (2010). "Building Information Modeling and Lean Construction: Technology , Methodology and Advances From Practice." Proceedings IGLC 18, Technion, Haifa, Israel, 683-693.

Han, S. H., Al-Hussein, M., Al-Jibouri, S., and Yu, H. (2012). "Automated postsimulation visualization of modular building production assembly line." Automation in Construction, Elsevier B.V., 21(1), 229-236.

Isaac, S., Bock, T., and Stoliar, Y. (2016). "A methodology for the optimal modularization of building design." Automation in Construction, Elsevier B.V., 65, 116-124.

Jensen, P., Olofsson, T., and Johnsson, H. (2012). "Configuration through the parameterization of building components." Automation in Construction, 23, 1-8.

Kong, L., Li, H., Luo, H., Lieyun, D., Luo, X., and Skitmore, M. (2017). “Optimal single-machine batch scheduling for the manufacture, transportation and JIT assembly of precast construction with changeover costs within due dates." Automation in Construction, Elsevier B.V., 81, 34-43.

Koskela, L. (2000). "An exploration towards a production theory and its application to construction." VTT Publications, (408).

Koskela, L., Ballard, G., Howell, G., and Tommelein, I. (2002). "The foundations of lean construction." Design and Construction: Building in Value, (December 2015), 211226.

Liu, J., and Lu, M. (2017). “Optimization on Supply-Constrained Module Assembly Process." 25th Annual Conference of the International Group for Lean Construction, Heraklion, Greece, 813-820.

McGraw Hill Construction. (2013). Lean construction - Leveraging collaboration and advanced practices to increase project efficiency. SmartMarketReport, Bedford.

McKinsey Global Institute. (2017). Reinventing construction: A route to higher productivity. McKinsey \& Company. 
Murphy, Z., Saripally, D., Dhakla, S., Trujillo, R., Luttmann, E., and Sreekumar, A. (2018). "Leveraging Advanced VDC Methods and Reality Capture to Increase the Predictability for Prefabrication.” 26th Annual Conference of the International Group for Lean Construction, Chennai, India, 101-111.

Nasereddin, M., Mullens, M. A., and Cope, D. (2007). "Automated simulator development: A strategy for modeling modular housing production." Automation in Construction, Elsevier B.V., 16, 212-223.

Pasquire, C., Soar, R., and Gibb, A. (2006). "Beyond Pre-Fabrication - the Potential of Next Generation Technologies to Make a Step Change in Construction Manufacturing." 14th Annual Conference of the International Group for Lean Construction, Santiago, Chile, 243-254.

Peñaloza, G. A., Viana, D. D., Bataglin, F. S., Formoso, C. T., and Bulhões, I. R. (2016). "Guidelines for Integrated Production Control in Engineer-to-Order Prefabricated Concrete Building Systems: Preliminary Results." 24th Annual Conference of the International Group for Lean Construction, Boston, USA.

Sacks, R., Akinci, B., and Ergen, E. (2003). "3D Modeling and Real-Time Monitoring in Support of Lean Production of Engineered-to-Order Precast Concrete Buildings." 11th Annual Conference of the International Group for Lean Construction, Virginia, USA.

Said, H. M., Chalasani, T., and Logan, S. (2017). "Exterior prefabricated panelized walls platform optimization." Automation in Construction, Elsevier B.V., 76, 1-13.

Sharafi, P., Samali, B., Ronagh, H., and Ghodrat, M. (2017). "Automated spatial design of multi-story modular buildings using a unified matrix method." Automation in Construction, 82, 31-42.

Tillmann, P., Viana, D., Sargent, Z., Tommelein, I., and Formoso, C. (2015). "BIM and Lean in the Design-Production Interface of ETO Components in Complex Projects." 23rd Annual Conference of the International Group for Lean Construction, O. Seppänen, V. A. González, and P. Arroyo, eds., Perth, Australia, 331-340.

Tiwari, S., Pawar, G., Luttmann, E., Trujillo, R., and Sreekumar, A. (2018). "Visual Planning for Supply Chain Management of Prefabricated Components in Construction." 26th Annual Conference of the International Group for Lean Construction, Chennai, India, 1150-1159.

World Economic Forum. (2016). Shaping the Future of Construction - A Breakthrough in Mindset and Technology. World Economic Forum (WEF), Geneva.

Xu, G., Li, M., Chen, C. H., and Wei, Y. (2018). "Cloud asset-enabled integrated IoT platform for lean prefabricated construction." Automation in Construction, Elsevier B.V., 93(September 2017), 123-134.

Yuan, Z., Sun, C., and Wang, Y. (2018). "Design for Manufacture and Assemblyoriented parametric design of prefabricated buildings." Automation in Construction, Elsevier B.V., 88, 13-22.

Zhong, R. Y., Peng, Y., Xue, F., Fang, J., Zou, W., Luo, H., Thomas Ng, S., Lu, W., Shen, G. Q. P., and Huang, G. Q. (2017). "Prefabricated construction enabled by the Internet-of-Things.” Automation in Construction, Elsevier B.V., 76, 59-70. 